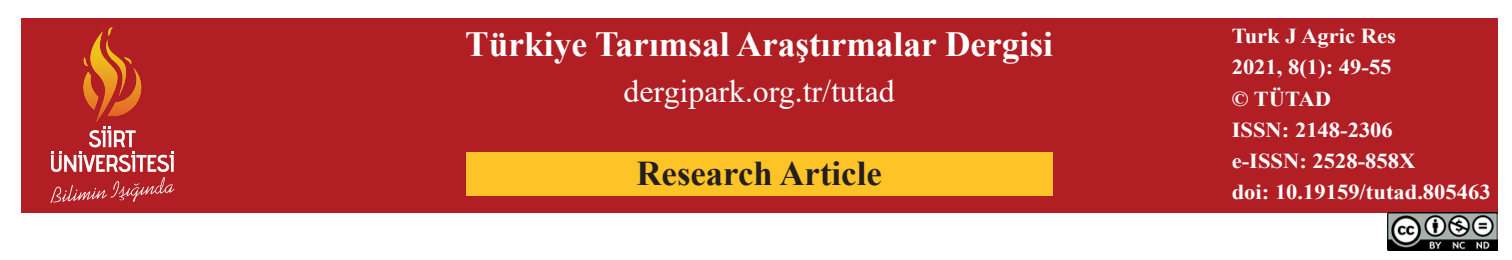

\title{
Synthesis and Characterization of Veronica beccabunga Green Synthesized Silver Nanoparticles for The Antioxidant and Antimicrobial Activity
}

\author{
Hamdullah SEÇKİN, İsmet MEYDAN* \\ Van Yüzüncü Yll University, Van Health Services Vocational School, Department of Health Technician, Van, TURKEY
}

\begin{tabular}{ll}
\hline \multicolumn{1}{c}{ Received: 05.10.2020 } & Accepted: 02.02.2021 \\
\hline ORCID ID (By author order) & \\
\hline (1) orcid.org/0000-0003-3884-4121 (1) orcid.org/0000-0001-5640-6665 \\
${ }^{*}$ Corresponding Author: ismetmeydan@yyu.edu.tr
\end{tabular}

\begin{abstract}
The use of nano-agents in the healthcare field is an important alternative in reducing the increasing pathogen resistance. One of the main purposes of the nano mechanism is that the secondary metabolites produced naturally in plants become more effective through metals. Silver (Ag) nanoparticles were obtained by green synthesis using Veronica beccabunga plant extract and $\mathrm{AgNO}_{3}$ in our study. Scanning electron microscopy was used for SEM, SEM / EDX images of synthesized silver nanoparticles. The interaction of $V$. beccabunga with Ag was explained by X-ray diffraction (XRD) analysis. The characterization process was performed using an ultraviolet-visible (UV-vis) spectrophotometer and Fourier converted infrared spectroscopy (FT-IR). It was determined that silver nanostructures have an important antioxidant potential as a result of 2,2-difenil-1-pikrilhidrazil (DPPH) analysis. The antimicrobial activity of synthesized metal nanoparticles was investigated, against some pathogens causing disease in humans, by the disk diffusion method. Ag NPs / $\mathrm{Vb}$ has been found to have antibacterial effects against Bacillus subtilis ATCC 6633, Escherichia coli ATCC 25952, Pseudomonas aeruginosa ATCC 27853 microorganisms. In our current study, $\mathrm{Ag} \mathrm{NPs} \mathrm{/} \mathrm{Vb} \mathrm{appears} \mathrm{to} \mathrm{provide} \mathrm{a} \mathrm{remarkable} \mathrm{effect} \mathrm{for} \mathrm{its} \mathrm{use} \mathrm{in} \mathrm{medicine,}$ pharmacology.
\end{abstract}

Keywords: Veronica beccabunga, antimicrobial, antioxidant, nanoparticle, characterization

\section{Introduction}

Metallic nanoparticles produced in different sizes and shapes can be used in many application areas. Nanoparticles come to the fore in applications such as medicine, electronics industry, agriculture, wastewater applications, antitumor and anticancer studies. The importance of metallic nanoparticles synthesized by biological applications for their antimicrobial and cytotoxic effects is increasing day by day (Patil and Kim, 2017). In particular, the antimicrobial effects of nanoparticles such as silver, copper, zinc, and gold have been reported (Mittal et al., 2013).

Antibiotics used today affect the cell wall, protein structures, lipid structures, and DNA structure in bacteria (Tenover, 2006; Wang et al., 2017). Nanoparticles (NPs), on the other hand, come into direct contact with the bacterial cell wall without penetrating the cell. Thus, although bacteria develop resistance against antibiotics, they cannot develop resistance against NPs.

Plants are known to have the potential to overaccumulate metallic ions and reduce them biologically. Because of these properties, plants have been considered to be a more environmentally friendly instrument for the bio-synthesis and detoxification of metallic nanoparticles (Mittal et al., 2014). Plant extracts and metal ions are subjected to bioreduction to form nanoparticles with the green synthesis method (Shah et al., 2015). Plant metabolites play an important role in the reduction and stabilization of metal ions to nanoparticles. Many plant species contain bioactive alkaloids, phenolic acids, polyphenols, proteins, sugars, and terpenoids (Koçak et al., 2020). Plants provide important advantages due to their low cost and not harming the environment. For this reason, 
plants are seen as the best choice for biological nanoparticle synthesis (Singh et al., 2016).

The Veronica beccabunga herb is a perennial plant belonging to the Asteraceae family. It is a shrubby plant that usually grows on riverside, fields, slopes, and steppes (Yaldız ve ark., 2010). $V$. beccabunga can grow in Europe, Asia, North Africa, and North America. In Turkey, it can be grown in the Black Sea, the Mediterranean, and in certain places in Anatolia (Yaşar et al., 2017). $V$. beccabunga is a bitter and aromatic herb that has been used as a medicine since ancient times. Nowadays $V$. beccabunga is used in the treatment of many diseases. It has been stated that the $V$. beccabunga has a good antifungal effect and a low degree of antibacterial effect. It has traditionally been used as an antiseptic, balsamic and antidepressant, against cholera and digestive disorders, as well as in the treatment of diuretic conditions, leukemia, and sclerosis. The $V$. beccabunga is known to be effective as a mild sedative for muscle relaxation and the treatment of anxiety (Dewick, 2001; Djilas et al., 2002).

The aim of this study was to investigate the effect of $V$. beccabunga collected from rural areas of Van-Turkey on human health. In this context, some biological and biochemical parameters were investigated.

\section{Materials and Methods}

\subsection{Preparation of plant extract}

$V$. beccabunga plant was collected in rural areas of Van-Turkey. The collected $V$. beccabunga was washed with distilled water and kept 7 days at room temperature to dry. The dried plants were powdered thoroughly with an electric blender. The powdered plant of $50 \mathrm{~g}$ was added into $250 \mathrm{~mL}$ of distilled water and heated in a mixer (Thermomac) at $80{ }^{\circ} \mathrm{C}$ for 15 minutes. The resulting extract was filtered through Whatman 1 filter paper and kept at $4{ }^{\circ} \mathrm{C}$ for further processes.

\subsection{Green synthesis of silver nanoparticles}

For the synthesis of Ag NPs, $1 \mathrm{mM} 500 \mathrm{ml}$ $\mathrm{AgNO}_{3}$ aqueous solution was prepared. $V$. beccabunga leaf extract of $100 \mathrm{ml}$ was allowed to react in a $1000 \mathrm{ml}$ flask at room temperature under constant conditions. The formation of silver nanoparticles was determined by the change of colorless solution to dark brown within 30-40 minutes. The nanoparticles obtained by green synthesis were separated by centrifugation (NF1200R) at 10.000 RPM for 5 minutes. This process was repeated three times to remove free silver ions. Obtained substances were left to dry in the oven and stored at $+4{ }^{\circ} \mathrm{C}$ for further processing.

\subsection{Characterization of $\mathrm{Ag} \mathrm{NPs} / \mathrm{Vb}$}

The formation of silver nanoparticles was performed using a UV device (Shimadzu UV2450), which measures the ultraviolet-visible (UVVis) absorption spectrum in the range of 200-800 $\mathrm{nm}$. The Ag NPs / Vb complex revealed the presence of phytochemicals with Fourier Transform-Infrared (FT-IR) named (Perkin ElmerSpectrum) in the range of $500-4000 \mathrm{~cm}^{-1}$. Measurements for X-ray diffraction (XRD) to illuminate the crystal structure of nanoparticles were made on a device (Panalytical Empyrean, Turkey), which contains an X-ray generator with copper $(\mathrm{Cu}) \mathrm{K} \alpha$ radiation $(40 \mathrm{kV}, \lambda=1.5406 \AA)$. By scanning the sample surface with a scanning electron microscope or scanning electron microscope (SEM), the topography and composition on the surface were taken. At the same time, the elemental analysis was performed with EDX (Zeiss Smart EDX).

\subsection{Antioxidant activity 2,2-difenil-1- pikrilhidrazil (DPPH) of Ag NPs / Vb}

The DPPH quenching activity of Ag NPs / Vb, the extract of the study subject, was calculated according to the Blois method (Blois, 1958). Butil hydroxyanisole (BHA) and Butil hydroxytoluene (BHT) were used as positive controls in this method. The experiment was performed using methanol solutions of $0,1 \mu \mathrm{g} \mathrm{ml}^{-1} \mathrm{DPPH}$. DPPH and extracts in the same ratio were prepared in 7 different concentrations of $5 \mu \mathrm{g} \mathrm{ml}^{-1}, 10 \mu \mathrm{g} \mathrm{ml}^{-1}, 15$ $\mu \mathrm{g} \mathrm{ml}^{-1}, 20 \mu \mathrm{g} \mathrm{ml}^{-1}, 25 \mu \mathrm{g} \mathrm{ml}^{-1}, 50 \mu \mathrm{g} \mathrm{ml}^{-1}$, and 100 $\mu \mathrm{g} \mathrm{m} \mathrm{m}^{-1}$. Ag NPs / Vb of $3 \mathrm{ml}$ extract and positive control were taken and DPPH solution was added to them. The mixtures formed in the tubes were incubated for 30 minutes at room temperature in the dark. At the end of this period, absorbance values were read at $517 \mathrm{~nm}$. This graph is obtained using Equation 1.

$\%$ Inhibition $(I)=[($ A control-A sample $) / A$ control $] \times 100$

As a result of these processes, a graph of Ag NPs / Vb concentration versus increasing DPPH ethanol concentration was obtained. This graph was obtained using the above equation.

\subsection{Antimicrobial activity}

Six pathogens were used to examine the antimicrobial activity of silver nanoparticles obtained from the $V$. beccabunga. The microorganisms used in the study are given in (Table 1). Standard strains were obtained from the Van Yüzüncü Y1l University of Eastern Anatolia in Turkey the Faculty of Science, Department of Biology. Neomycin $(10 \mu \mathrm{g})$ antibiotic was used as the control group. The antimicrobial activity of $\mathrm{Ag}$ 
NPs / Vb was determined by the disk diffusion method (Ibraheem et al., 2016). Tryptic soy broth was used for the activation of microorganisms and Nutrient Agar media were used for the Disk diffusion method.

Table 1. Microorganisms used in the study

\begin{tabular}{l}
\hline Bacteria \\
\hline Bacillus cereus ATCC 10876 \\
Bacillus subtilis ATCC 6633 \\
Escherichia coli ATCC 25952 \\
Pseudomonas aeruginosa ATCC 27853 \\
Staphylococcus aureus ATTC 29213 \\
\hline Fungus \\
\hline Candida albicans ATTC 90028 \\
\hline
\end{tabular}

\section{Results and Discussion}

\subsection{Characterization of silver nanoparticles}

SEM / SEM-EDX, FT-IR, XRD, and UV-Vis techniques respectively were used for the structural and morphological characterization of $\mathrm{Ag}$ nanoparticles prepared with green synthesis using $V$. beccabunga plant. SEM images of the Ag NPs / $\mathrm{Vb}$ sample taken at different scales and the EDX spectrum obtained from one of these images (Figure 1). It can be seen from SEM images of different scales that Ag nanoparticles are homogeneously distributed. In the EDX spectrum, it is seen that there are $\mathrm{Ag}$, carbon $(\mathrm{C})$, and oxygen $(\mathrm{O})$ elements that form the structure of the Ag NPs / Vb sample.



Figure 1. (a-b) SEM images and (c) corresponding EDX spectrum of Ag NPs / Vb

In addition, it has been observed that there are different metals thought to be in the structure of the plant.

The FT-IR image shows (Figure 2) the peaks formed by functional groups (phenolic, flavonoid, gallic acid, coumarin) in the structure of $V$. beccabunga, the current plant in the range of $500-2000 \mathrm{~cm}^{-1}$. It is seen that these peaks decrease or disappear in Ag NPs / Vb. The peaks in between are thought to belong to many organic components, while the sharp peak at $3000-3500 \mathrm{~cm}^{-1}$ belongs to the $\mathrm{C}-\mathrm{H}$ organic component.

XRD technique was used to determine the crystal structure of silver nanoparticles. Considering the spectrum, different peaks are seen (Figure 3). It was determined that Ag NPs have different breaking peaks as $32.54^{\circ}, 47.05^{\circ}, 66.43^{\circ}$, and $77.02^{\circ}$ against $\mathrm{Ag}$ (111), Ag (200), Ag (220), and $\mathrm{Ag}(311)$ planes. It is seen that the data obtained are compatible with the literature studies (Fatemeh et al., 2017). 


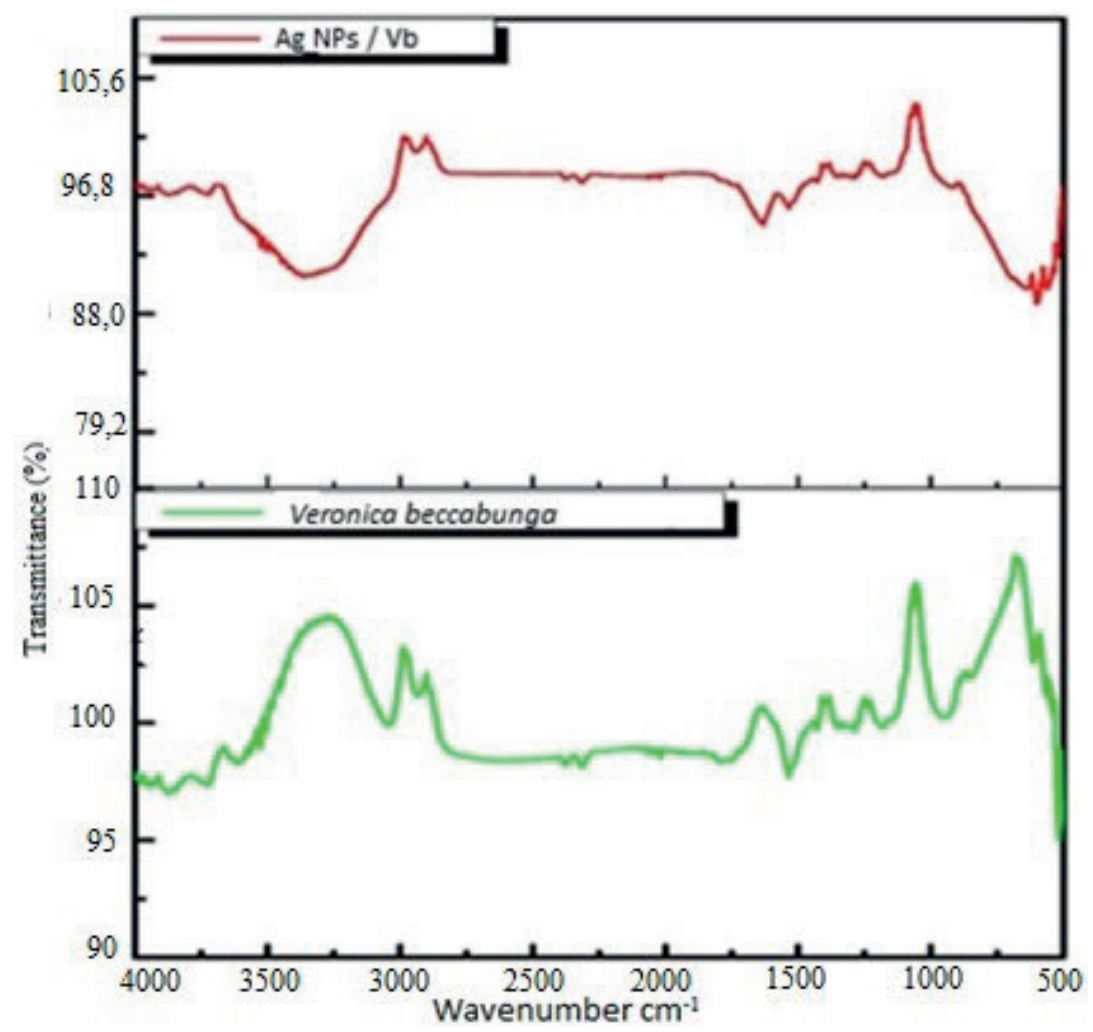

Figure 2. FT-IR spectra of $\mathrm{Vb}$ and $\mathrm{Ag} \mathrm{NPs} / \mathrm{Vb}$ samples

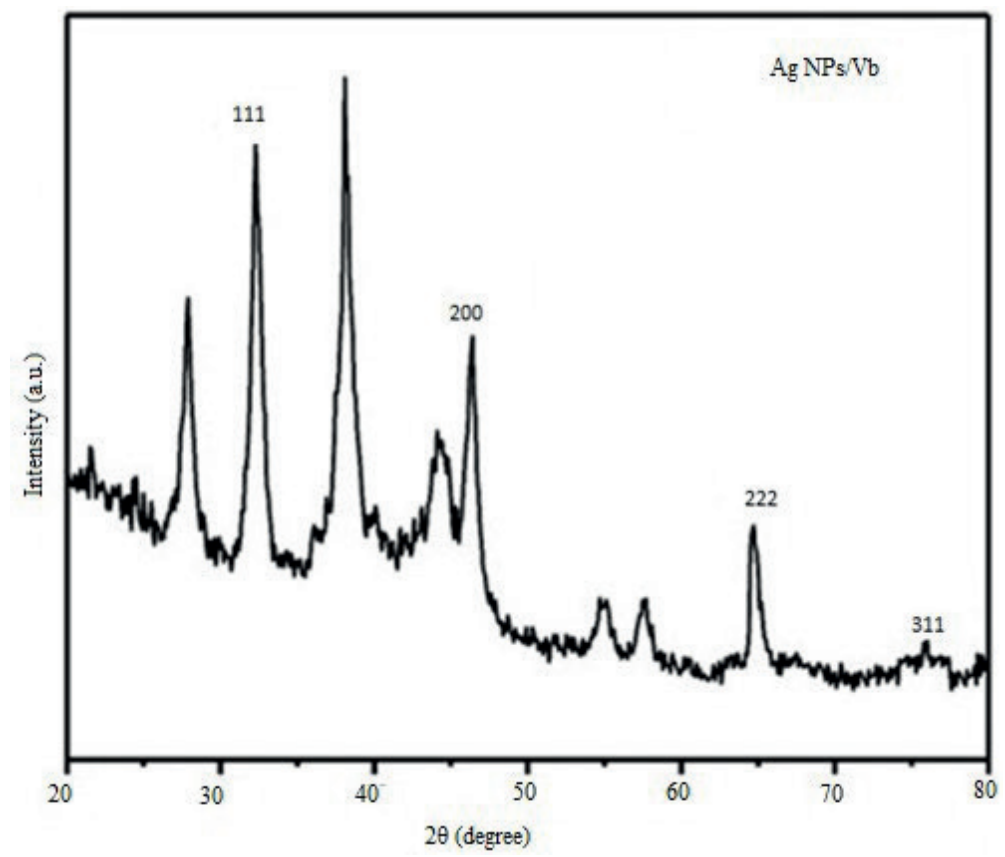

Figure 3. XRD pattern of $\mathrm{Ag} \mathrm{NPs} / \mathrm{Vb}$

In Figure 4, it is seen that the $\mathrm{AgNO}_{3}$ compound analyzed using $\mathrm{UV}-\mathrm{V}$ is spectroscopy gives a strong peak at $420 \mathrm{~nm}$ wavelength. It is understood that the given peak is in line with the literature data (Selvam et al., 2017; Nazar et al., 2018). After the Ag NPs
$/ \mathrm{Vb}$, the existing peak appears to have dropped significantly. For this, it can be said that the peak formed has disappeared because $\mathrm{Ag}$ is reduced to $\mathrm{Ag}^{+1}-\mathrm{Ag}^{0}$ due to the transition between electrons in NPs / Vb. 


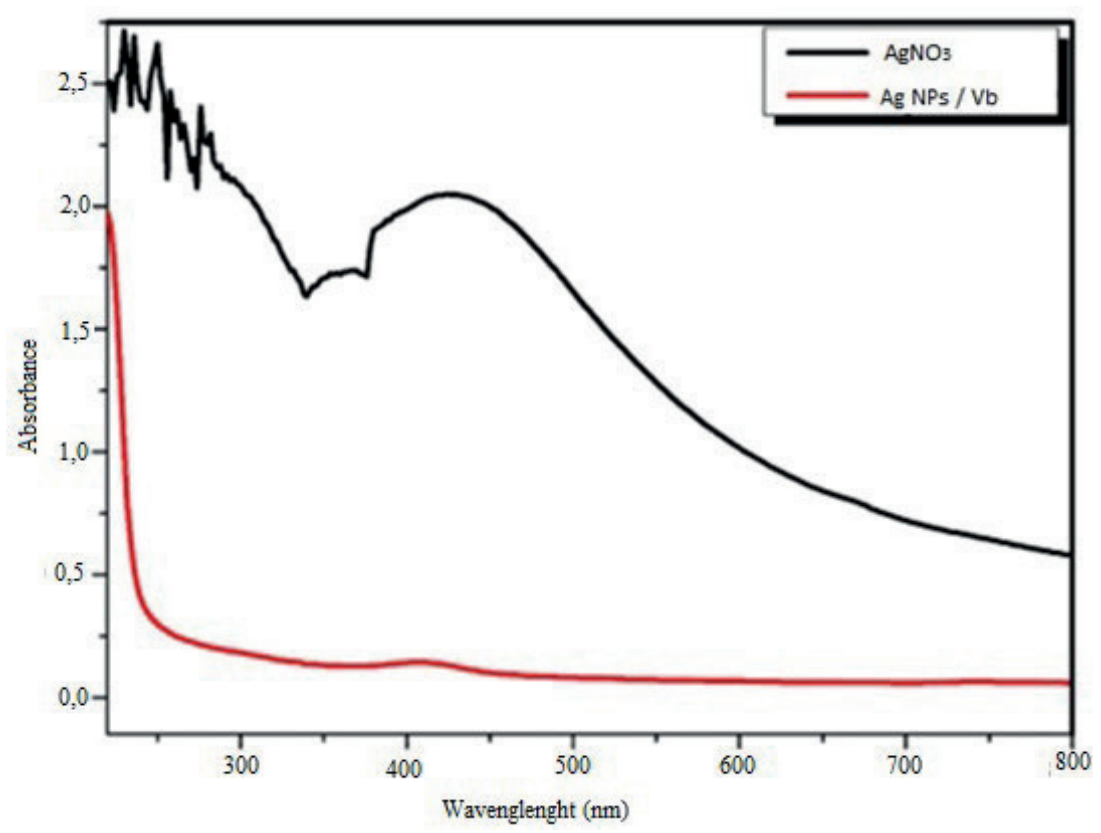

Figure 4. UV-vis spectra of $\mathrm{Vb}, \mathrm{AgNO}_{3}$, and $\mathrm{Ag} \mathrm{NPs} / \mathrm{Vb}$ samples

\subsection{Antimicrobial activity}

The antimicrobiality of Ag NPs obtained by using $V$. beccabunga plant and $\mathrm{AgNO}_{3}$ was investigated. Silver nanoparticles obtained from the Musa acuminata plant showed activity against Pseudomonas aeruginosa (Valsalam et al., 2019). Silver nanoparticles (AgNPs) obtained from Ocimum sanctum (basil) leaves formed an inhibition zone against Staphylococcus aureus, Escherichia coli, and Candida albicans strains (Aazam and Zaheer, 2016). In the study, it was determined that the extract obtained from $V$. beccabunga created a weak inhibition zone (Table 2) against Bacillus subtilis ATCC 6633 and Escherichia coli ATCC 25952. On the other hand, Ag NPs /Vb clusters were observed to affect Bacillus subtilis ATCC 6633, Escherichia coli ATCC 25952, and Pseudomonas aeruginosa ATCC 27853 (Table 2). Therefore, it was determined that silver nanoparticles have an antibacterial effect against some bacteria. In addition, it was determined that it did not show an antifungal effect against Candida albicans ATTC 90028.

Table 2. Antimicrobial activity results

\begin{tabular}{|c|c|c|c|}
\hline Test microorganisms & & jition zone $(\mathrm{n}$ & \\
\hline Bacteria & Extract & $\mathrm{Ag} \mathrm{NPs} / \mathrm{Vb}$ & Neomycin \\
\hline Bacillus cereus ATCC 10876 & & & $16 \pm 5.0$ \\
\hline Bacillus subtilis ATCC 6633 & $10 \pm 1.4$ & $14 \pm 3.2$ & $20 \pm 4.2$ \\
\hline Escherichia coli ATCC 25952 & $8 \pm 2.5$ & $9 \pm 2.0$ & $12 \pm 5.5$ \\
\hline Pseudomonas aeruginosa ATCC 27853 & & $10 \pm 4.5$ & \\
\hline Staphylococcus aureus ATTC 29213 & & & $16 \pm 1.0$ \\
\hline Fungus & & & \\
\hline Candida albicans ATTC 90028 & & & $21 \pm 2.2$ \\
\hline
\end{tabular}

\subsection{Antioxidant activity 2,2-difenil-1- pikrilhidrazil (DPPH)}

DPPH radical quenching activity is the safest, highly valid, cheap, accurate, fast, easy, and economical method used to measure total antioxidant activity (Sharma and Bhat, 2009; Deng et al., 2011) By adding an antioxidant solution to the DPPH solution, antioxidants reduce radicals by giving them protons (Kedare and Singh, 2011). As a result of the reduction, the color of the solution changes from purple-violet to yellow and there is a decrease in the absorbance at the measured wavelength (Haida and Hakiman, 2019). This color change is usually measured spectrophotometrically at $517 \mathrm{~nm}$. In Figure 5, the antioxidant activity of Ag NPs / Vb was compared with positive control BHA and BHT. DPPH radical quenching activities at the highest concentration of $100 \mu \mathrm{g} \mathrm{ml}^{-1}$ are 


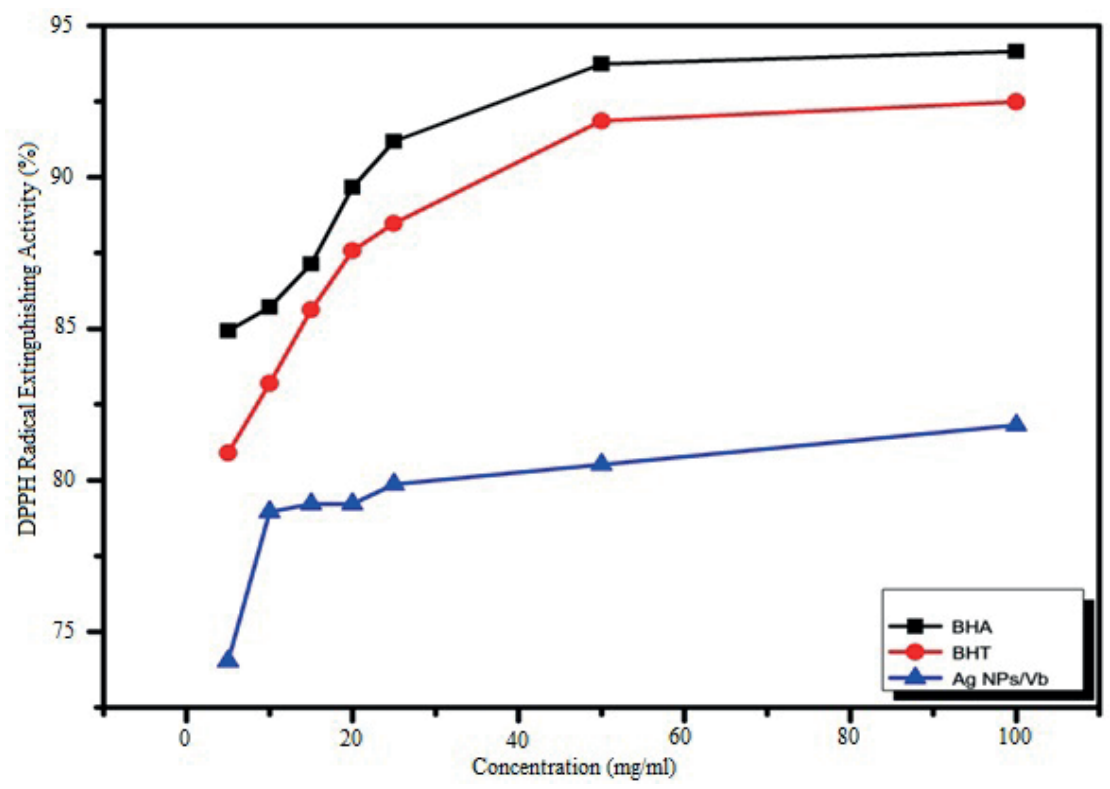

Figure 5. DPPH Radical extinguish Activity of Ag NPs / Vb

$94.021 \%$ for BHA, $92.024 \%$ for BHT, and $81.245 \%$ for $\mathrm{Ag} \mathrm{NPs} / \mathrm{Vb}$. V. beccabunga green synthesis study has not been found in the literature. Antioxidant studies related to the natural structure of the plant are available in the literature. In previous studies, the antioxidant activity of $V$. beccabunga plant was investigated and it was determined that it is a good antioxidant (Nikolova, 2011; Nóra et al., 2019). When compared with the studies in the literature, $\mathrm{Ag} \mathrm{NPs} / \mathrm{Vb}$ seems to increase the potential antioxidant activity.

\section{Conclusions}

The use of nano-sized structures at the biomedical level has made important progress in sterilization, disinfection, and pharmaceutical industries. New ones are added to promising nanotechnological studies every day. It is thought that Ag NPs / Vb synthesized in this study can form a basis for further studies and contribute to the development of pharmacological treatments and non-toxic alternatives. Analyzes show that AgNPs have good antioxidant potential. Looking at the antimicrobial properties of silver nanoclusters, it was determined that they formed an inhibition zone against some pathogen bacteria. It is predicted that Ag NPs / Vb structures can contribute to the production of new antibacterial drugs and will become an important factor in the field of health and biotechnology as a result of more comprehensive studies.

\section{References}

Aazam, E.S., Zaheer, Z., 2016. Growth of Agnanoparticles in an aqueous solution and their antimicrobial activities against Gram-positive, Gramnegative bacterial strains and Candida fungus. Bioprocess and Biosystems Engineering, 39(4): 575584.

Blois, M.S., 1958. Antioxidant determinations by the use of a stable free radical. Nature, 181(4617): 11991200.

Deng, J., Cheng, W., Yang, G., 2011. A novel antioxidant activity index (AAU) for natural products using the DPPH assay. Food Chemistry, 125(4): 1430-1435.

Dewick, P.M., 2001. Medicinal Natural Products. Biosynthetic Approach, New York: Wiley.

Djilas, S.M., Canadanovic-Brunet, J.M., Cetkovic, G.S., 2002. ESR spectroscopic investigation of antioxidant activity of Artemisia absinthium L. extracts. 6th International Conference on Applications of Magnetic Resonance in Food Science, September 18, Paris, France, pp. 40-45.

Fatemeh, K., Mohammad, J.M., Samaneh, K., 2017. The effect of silver nanoparticles on composite shear bond strength to dentin with different adhesion protocols. Journal of Applied Oral Science, 25(4): 367-373.

Haida, Z., Hakiman, M., 2019. A comprehensive review on the determination of enzymatic assay and nonenzymatic antioxidant activities. Food Science \& Nutrition, 7(5): 1555-1563.

Ibraheem, I.B.M., Abd Elaziz, B.E.E., Saad, W.F., Fathy W.A., 2016. Green biosynthesis of silver nanoparticles using marine red algae Acanthophora specifera and its antimicrobial activity. Journal of Nanomedicine Nanotechnology, 7(6): 1-4.

Kedare, S.B., Singh, R.P., 2011. Genesis and development of DPPH method of antioxidant assay. Journal of Food Science and Technology, 48(4): 412422.

Koçak, Y., Oto, G., Meydan, İ., Seçkin, H., 2020. Investigation of total flavonoid, DPPH radical 
scavenging, lipid peroxidation and antimicrobial activity of Allium schoenoprasum L. plant growing in Van Region. Yüzüncü Yll University Journal of Agricultural Science, 30(1): 147-155. (In Turkish).

Mittal, A.K., Chisti, Y., Banerjee, U.C., 2013. Synthesis of metallic nanoparticlesusing plant extracts. Biotechnology Advances, 31: 346-356.

Mittal, J., Batra, A., Singh, A., Sharma, M.M., 2014. Phytofabrication ofnanoparticles through plant as nanofactories. Advances in Natural Sciences, 5(4): 110.

Nazar, R., Sangermano, M., Vitale, A., Bongiovanni, R., 2018. Silver polymer nanocomposites by photoreduction of $\mathrm{AgNO}_{3}$ and simultaneous photocrosslinking of the acrylic matrix: effect of PVP on Ag particle formation. Journal of Polymer Engineering, 38: 803-809.

Nikolova, M., 2011. Screening of radical scavenging activity and polyphenol content of Bulgarian plant species. Pharmacognosy Research, 3(4): 256-259.

Nóra, P., Nikolett, S., Rit, C., Monika, T., King, G., Tünde, D., Samuel, G.B., Erzsébet, V., Andrea, K., Tamás, K., 2019. Antioxidant potential of some plants used in folk medicine in Romania. Soc Stunte Farmaceutıce Romania, 67(2): 323-330.

Patil, M.P., Kim, G.D., 2017. Eco-friendly approach for nanoparticles synthesis andmechanism behind antibacterial activity of silver and anticancer activity ofgold nanoparticles. Applied Microbiology and Biotechnology, 101: 79-92.

Selvam, K., Sudhakar, C., Govarthanan, M., Thiyagarajan, P., Sengottaiyan, A., Senthilkumar, B., Selvankumar, T., 2017. Eco-friendly biosynthesis and characterization of silver nanoparticles using Tinospora cordifolia (Thunb.) Miers and evaluate its antibacterial, antioxidant potential. Journal of
Radiation Research and Applied Sciences, 10(1): 612.

Shah, M., Fawcett, D., Sharma, S., Tripathy, S., Poinern, G., 2015. Green synthesis of metallic nanoparticles via biological entities. Materials, 8(11): 7278-7308.

Sharma, O.P., Bhat, T.K., 2009. DPPH antioxidant assay revisited. Food Chemistry, 113(4): 1202-1205.

Singh, P., Kim,Y.J., Zhang, D., Chun-Yang, D., 2016. Biological synthesis of nanoparticles from plants and microorganisms. Trends in Biotechnology, 34(7): 588-599.

Tenover, F.C., 2006. Mechanisms of antimicrobial resistance in bacteria. The American Journal of Medicine, 119(6): 3-10.

Valsalam, S., Agastian, P., Esmail, G.A., Ghilan, A.K.M., Al-Dhabi, N.A., Arasu, M.V., 2019. Biosynthesis of silver and gold nanoparticles using Musa acuminata colla flower and its pharmaceutical activity against bacteria and anticancer efficacy. Journal of Photochemistry and Photobiology B: Biology, 201(4): 210-225.

Wang, L., Hu, C., Shao, L., 2017. The antimicrobial activity of nanoparticles: present situation and prospects for the future. International Journal of Nanomedicine, 12: 1227-1249.

Yaldız, G., Yüksek, T., Şekeroğlu, N., 2010. Medicinal and aromatic plants in flora of Rize province and their usage areas. $3^{\text {rd }}$ National Black Sea Forestry Congress, 20-22 May, Artvin, Turkey, pp.1100-1114. (In Turkish).

Yaşar, S., Güler, G., Beram, A., Coşkun, D., Ozansoy, D., 2017. Volatile components of wormwood (Artemisia absinthium L.) leaves. The Journal of Graduate School of Natural and Applied Sciences of Mehmet Akif Ersoy University, 8(2): 148-152. (In Turkish). 